\title{
Educational Quality Assurance in Thailand: A Literature Review
}

\author{
Pannarat Wansavatkul Kadish \\ Suryadhep Teachers College, Rangsit University \\ 52347 Phahonyothin Rd, Tambon Lak Hok, Amphoe Mueang \\ Pathum Thani, Thailand 12000
}

\begin{abstract}
Quality is one crucial reason for people in choosing an educational institution in Thailand or anywhere in the world. By this time, there are many ways to manage educational quality to gain trust from customers and to have a decent potential to compete with competitors as well. Quality assurance is one way to manage educational quality as it is a system to ensure the educational quality to stakeholders. Educational quality assurance is a system for building confidence, satisfaction, and operation development, which can be monitored and selfassessed. Internal quality assurance is the audit, control, monitoring, evaluation of quality according to educational standards of educational institutions from the inside by personnel of institutions entirely or by the primary affiliation responsible for overseeing those educational institutions. The results of the internal quality audit are systematic work and precise mechanisms, which include operations and database development in various fields. External quality assurance is the evaluation of educational management quality, monitoring, the audit of educational quality and standards of educational institutions, which are performed by external agencies or external assessors. With this regard, it is a challenge for educational institutions in needing to keep improving their quality and sustain professional learning communities continuously, as the goal of having an educational quality assurance system is to ensure that learners have the best learning opportunities possible. Educational quality assurance is a big part of educational improvement in the nationwide.
\end{abstract}

Keywords: Internal quality assurance, External quality assurance, Educational quality assurance

DOI: $10.7176 /$ PPAR/9-7-03

Publication date:July $31^{\text {st }} 2019$

\section{Introduction}

In the past, people would mostly choose famous schools, which had a good school history and were well accepted by people in society. Lots of people emphasize taking competitive exams. Such characteristics of values in choosing schools for children have existed since decades ago. However, nowadays considerations also include various factors, e.g., a success rate of alumni who can move up to the right school or get an excellent job in a good company, quality of teachers, vision of the executives, educational media, technology, and learning sources. Despite those factors, there will always be other factors that affect the image and the operations of schools. Therefore, the educational quality assurance system plays a vital role, which will allow schools to develop into high standards. However, many schools still struggle to develop to meet the required standards. As a result, the current educational system does not progress as much as it should be.

\section{Educational Quality Assurance in Thailand}

National Education Act 1999 (B.E. 2542) and the amendments (No. 2) 2002 (B.E. 2545) have established the purposes and principles of educational management with a focus on educational quality and standards.

The details stated in Chapter 6: Standards and educational quality assurance Section 47 requiring the educational quality assurance systems to develop educational quality and standards at all levels, including internal quality assurance systems and external quality assurance systems.

Internal Quality Assurance: Section 48 requires the primary affiliation and educational institutions to provide a quality assurance system within educational institutions. Moreover, the internal quality assurance must be considered as part of the educational management process, which must be carried out continuously by making an annual report for submission to the original affiliation, relevant agencies and public disclosure to lead to the development of educational quality and standards and to support external quality assessment.

External Quality Assurance: Section 49 requires the Office for National Education Standards and Quality Assessment as a public organization to act to develop the rules, methods for external quality assessment and evaluate educational management. The objective is to ensure the educational institutions quality audit by taking into account of purposes and principles as well as guidelines for educational management at each level as specified in the Education Act. External quality assessment of all educational institutions is required at least once every five years since the last assessment. Also, the evaluation results must be presented to relevant agencies and the public.

The systems, rules, and methods for educational quality assurance shall be as stipulated in the ministerial regulations. There are two regulations of the Education Ministry as follows: 
Ministerial regulations on the systems, rules, and methods for educational quality assurance at primary education level 2003 (B.E. 2546) Clause 2, paragraph 2 stipulated that an educational quality assurance system in educational institutions is part of educational management, which is a continuous educational quality development process. The development process consists of:
1. Management and information system
2. Development of educational standards
3. The educational quality development plan arrangement
4. Implementation of the educational quality development plan
5. Audit and review of educational quality
6. Educational quality assessment
7. Reporting of annual educational quality
8. Maintenance of educational quality assurance system

Ministerial regulations on the systems, rules, and methods for educational quality assurance in higher education institutions 2003 (B.E. 2546), Clause 6 (1) prescribing the systems and mechanisms for educational quality assurance of the Faculties and higher education institutions by taking into account the components of higher education quality as follows:
1. Philosophy, resolution, objectives and operational plan
2. Learning and teaching
3. Student development activities
4. Research
5. Academic services for society
6. Upholding art and culture
7. Administration and management
8. $\quad$ Finance and budget
9. Educational quality assurance systems and mechanisms

\section{The Objectives of Educational Quality Assurance}

1. To know the levels of quality of educational institutions in performing various missions.

2. Encouraging educational institutions to develop educational quality and management efficiency continuously

3. To know the progress in educational quality development of educational institutions.

4. To report the condition of quality as well as standards of educational institutions to the public and relevant agencies.

5. To verify the actual conditions of operations of educational institutions and evaluate educational quality based on educational standards effectively according to specified guidelines and methods and inconsistency with educational quality assurance systems of educational institutions and the primary affiliation.

6. To obtain information that helps reflect the strengths - the points which improve educational institutions, the conditions of success, and the causes of problems.

7. To provide suggestions on improving and developing educational quality for educational institutions and the primary affiliation.

8. To encourage educational institutions to develop quality and internal quality assurance continuously.

9. To report the results of evaluating educational quality and standards of educational institutions to the public and related agencies.

\section{The Educational Quality Assurance Process}

\section{Quality Control}

Quality Control is the operational process of the primary affiliation and educational institutions for determining educational standards in line with national educational standards. After that, the primary affiliation and educational institutions make a plan as operational guidelines on the development of quality into standards specified in the development of curricula, media, teacher and personal development, statutes of educational institutions, teaching regulations, guidance, educational management, and evaluation.

In this regard, emphases will be placed on the systems and mechanisms of operations according to the plan, monitoring the operations seriously and continuously.

\section{Quality Audit}

Quality audit is the operation of educational institutions and the primary affiliation to confirm the specified target geared towards the desired standards by taking action as follows:

Self -audit, and review of the whole system's operations of educational institutions in order to 
bring information to improve and develop educational management consistently and report the results to parents and people responsible for educational management.

Audit and review of the educational quality of educational institutions by the original affiliation to promote, support and take measures to encourage the development of educational quality under the established educational standards.

\section{Quality Assessment}

Quality assessment is the evaluation of quality levels for specific activities in the organizations such as quality of educational management, quality of research, quality of teaching.

Internal quality assessment is conducted by self-study and self-assessment report, while external quality assessment is conducted by the Office for National Education Standards and Quality Assessment (ONESQA). ONESQA is an assessor who evaluates and certifies that educational institutions provide quality educational management according to the established educational standards.

\section{Benefits of Educational quality assurance}

1. Continuous improvement of quality of educational institutions into international standards

2. Efficient use of resources in the management of higher education institutions

3. Management of educational institutions is sufficient, thus making the production of graduates at all levels, creation of researches and academic services achieve maximum benefit and meet the needs of society and the nation.

4. The students, parents, employers, and the public have information for correct and systematic decisions.

5. Educational institutions, educational service agencies, and the government have correct and systematic information for determining the policy, planning, and organizing educational services.

6. The students' academic achievement in all subjects is high and meets the standards consistently.

7. The students know in advance what results will obtain from studying in educational institutions and get the desired results.

8. The parents, communities, teachers, local educational management agencies take part in setting quality standards that blend international standards, national standards, and local standards.

9. The administrators of educational institutions are leaders in management to control educational quality by joining forces with the teachers, board of educational institutions, parents, communities in planning to enhance educational quality in order to be valid for the students according to standards. There is the audit, acceptance of operational plans of educational institutions.

10. The teachers are developed and motivated to plan educational management by taking the students as a center, emphasizing the practice process to achieve complete learning quality standards, allowing all students to learn to their full potential. The administrators and the board of educational institutions monitor the teaching and learning and help educational quality to be systematic, orderly.

11. There is a system for evaluating the actual conditions, focusing directly on achieving quality standards and recording in the files of the administrators and teachers checking the learning results, and recording the results. The results are used for development and reporting to the communities regularly on how educational management is sufficient to achieve the results according to pre-determined learning quality goals.

\section{Conclusion}

Internal quality assessment will directly affect external quality assurance. External quality assurance will use the indicators according to various standards for evaluating the operations of educational institutions, including visits to institutions. Assessment must take into account the philosophy, mission, and characteristics of educational management of each educational institution. The educational institutions must prepare an annual report in various fields, including information based on the indicators and self-assessment at least three academic years. These reports can be made in the form of CD -ROM or E-SAR to be ready to get an external assessment from the Office for National Education Standards and Quality Assessment (ONESQA).

Likewise, educational quality assurance assessment can be as such useful information that facilitates the educational management, prevent problems, operation efficiency and gradually lead to improvement and sustainability in educational quality within an educational institution and education among the nationwide.

\section{References}

National Education Commission, Office. (2011). Guidelines for Educational Quality Assurance According to Basic Education Standards for Internal Quality Assurance of Educational Institutions. Bangkok: National Buddhism Office Printing Press

Necessary Education Commission, Office. (2011). Continuous Educational Quality Development: Ministerial Regulations on Systems, Rules, and Methods for Educational Quality Assurance, 2010. 1st Edition. 
Bangkok: The Agricultural Co-operative Federation of Thailand., LTD Printing Press

Necessary Education Commission, Office. (2011). Guidelines for Development of Internal Quality Assurance System of Educational Institutions: Ministerial Regulations on Systems, Rules, and Methods for Educational Quality Assurance, 2010. 1st Edition. Bangkok: The Agricultural Co-operative Federation of Thailand., LTD Printing Press

National Education Commission, Office. (2002). National Education Act, 1999 and Amendments (No. 2$) 2002$. Bangkok: Religious Affairs Pri 